\title{
Effect of Chemical Constituents on the Formation Rate of Carbon Monoxide in Bright Tobacco*
}

\author{
by $T$. Yamamoto, Y. Suga, K. Kaneki and H. Kaneko \\ Central Researcb Institute, Japan Tobacco Inc., Yokohama, Japan
}

\section{SUMMARY}

- From cigarettes made of different bright tobaccos but with a constant fractional volume, the following results were obtained. The rate of formation of $\mathrm{CO}$ was a more influential factor determining the amount of $\mathrm{CO}$ in mainstream smoke than the weight loss of the cigarette during puffs. From a stepwise multiple regression analysis it was found that the rate of formation of $\mathrm{CO}$ was mainly dependent on the potassium content of the tobacco and could be estimated from the amounts of potassium, total carbon, and lignin. The rate of formation of $\mathrm{CO}$ increased with a rise in combustion temperature, which in turn rose as the potassium content of the tobacco decreased.

\section{ZUSAMMENFASSUNG}

Eine Untersuchung von Zigaretten mit einem konstanten Anteil an verschiedenen hellen Tabaksorten erbrachte folgende Ergebnisse: Die Geschwindigkeit der Bildung von Kohlenmonoxid hatte einen größeren Einfluß auf die im Hauptstromrauch enthaltene Menge an Kohlenmonoxid als der Gewichtsschwund der Zigarette während der Rauchzüge. Eine stufenweise durchgeführte multiple Regressionsanalyse ergab, daß die Geschwindigkeit der Kohlenmonoxidbildung vor allem eine Funktion der im Tabak enthaltenen Kaliummenge ist und sich aus den Kalium-, Gesamtkohlenstoff- und Ligningehalten abschätzen läßt. Die Geschwindigkeit der Bildung von Kohlenmonoxid erhōhte sich mit ansteigender Verbrennungstemperatur, welche wiederum mit abnehmendem Kaliumgehalt des 'Tabaks zunahm.

\footnotetext{
* Received: 16th April 1986 - 2ccepted: 28th April 1988.
}

\section{RESUME}

Une êtude effectuée sur des cigarettes ayant une proportion constante de différentes variérés de tabac blond a conduit aux résultats suivants: la quantité de monoxyde de carbone contenue dans la fumée du courant principal dépend davantage de la vitesse de formation du monoxyde de carbone que de la diminution de poids de la cigarette pendant les bouffées. Une analyse de régression multiple réalisée par étapes a montré que la vitesse de formation du monoxyde de carbone était avant tout fonction de la quantite de potassium contenue dans le tabac et qu'il était possible de l'estimer à partir des teneurs en potassium, carbone total et lignine. $\mathrm{La}$ vitesse de formation du monoxyde de carbone augmente avec la température de combustion laquelle s'élève lorsque la teneur en potassium diminue.

\section{INTRODUCTION}

It is well known that the amount of carbon monoxide in mainstream smoke decreases as the ventilation of the filter and the permeability of the cigarette paper increase $(1,2)$. As for the effect of the kind of tobacco on $\mathrm{CO}$ delivery, several investigations have been carried out with cigarettes made of various tobaccos which differed with respect to cultivar and stalk position (35 ), and correlations were demonstrated between the smoke components, including $\mathrm{CO}$, and various chemical constituents of the tobaccos (6). However, there has as yet been no report on the interrelation between the amount of $\mathrm{CO}$ in mainstream smoke, the chemical constituents of the tobaccos, and the burning characteristics, i.e. the rate of formation of $\mathrm{CO}$ (the ratio of $\mathrm{CO}$ delivery to the weight loss of tobacco during puffs) 
and the amount of tobacco consumed during puffs. The amount of $\mathrm{CO}$ in mainstream smoke (A) can be expressed by the following equation:

$$
A[\mathrm{mg} / \mathrm{cig} .]=\mathrm{n} \mathrm{W}_{\mathrm{p}} \mathrm{FD} \text {, }
$$

where $\mathrm{n}$ is the puff count, $W_{\mathrm{p}}$ is the weight loss during a puff, $F$ is the rate of formation of $C O$, and $D$ is a factor relating to the loss of $\mathrm{CO}$ through the cigarette paper by diffusion. The product of $n$ and $W_{p}, n W_{p}$, is regarded as the quantity of tobacco burned during $n$ puffs, and $F$ as a qualitative factor concerning the burning of tobacco during a puff. $\mathrm{D}$ is considered to be constant under standard smoking conditions when the lengths of the cigarettes in contact with air are constant (7-9).

We investigated the importance of the rate of formation of $\mathrm{CO}$ for the amount of $\mathrm{CO}$ in mainstream smoke and the effect of chemical constituents on the rate of formation of $\mathrm{CO}$.

\section{EXPERIMENTAL}

\section{Cigarette Samples}

Unblended non-filter cigarettes were made of the leaf and cutter of five kinds of bright tobacco cultivars. The width of the cut shreds was $0.8 \mathrm{~mm}$, and ordinary cigarette paper (permeability: about $10 \mathrm{ml} / \mathrm{cm}^{2} / \mathrm{min} /$ $100 \mathrm{~mm}$ w.g.) was used. The length and circumference of the cigarette were $70 \mathrm{~mm}$ and $25 \mathrm{~mm}$, respectively. After conditioning at $22{ }^{\circ} \mathrm{C}$ and $60 \%$ relative humidity, cigarettes were selected at the weight and pressure drop shown in Table 1 . The weight of each sample was selected to keep the fractional volume of the cigarette constant $(0.30)$. The apparent density of the shreds, which was necessary for deciding the fractional volume, was measured by a mercury displacement method (10).

Table 1.

Weight and pressure drop of cigarette samples.

\begin{tabular}{|c|c|c|c|}
\hline \multicolumn{2}{|c|}{ Tobacco } & $\begin{array}{l}\text { Weight } \\
\text { (g) }\end{array}$ & $\begin{array}{l}\text { Pressure drop } \\
\text { (mm w.g.) }\end{array}$ \\
\hline A & $\begin{array}{l}\text { Cutter } \\
\text { Leaf }\end{array}$ & $\begin{array}{l}0.939 \\
0.963\end{array}$ & $\begin{array}{l}51-56 \\
38-43\end{array}$ \\
\hline B & $\begin{array}{l}\text { Cutter } \\
\text { Leaf }\end{array}$ & $\begin{array}{l}0.872 \\
0.924\end{array}$ & $\begin{array}{l}32-34 \\
28-30\end{array}$ \\
\hline C & $\begin{array}{l}\text { Cutter } \\
\text { Leaf }\end{array}$ & $\begin{array}{l}0.901 \\
1.001\end{array}$ & $\begin{array}{l}31-33 \\
28-30\end{array}$ \\
\hline D & $\begin{array}{l}\text { Cutter } \\
\text { Leaf }\end{array}$ & $\begin{array}{l}0.909 \\
0.926\end{array}$ & $\begin{array}{l}65-71 \\
40-45\end{array}$ \\
\hline $\mathbf{E}$ & $\begin{array}{l}\text { Cutter } \\
\text { Leaf }\end{array}$ & $\begin{array}{l}0.834 \\
0.929\end{array}$ & $\begin{array}{l}58-64 \\
34-36\end{array}$ \\
\hline
\end{tabular}

Fractional volume of cigarettes : 0.30 .
Smoking Conditions and

Measurement of Formation Rates of $\mathrm{CO}$ and $\mathrm{CO}_{2}$

The cigarettes were smoked to a $30 \mathrm{~mm}$ butt length on a smoking machine (Filtrona, model 302) under standard smoking conditions. The methods of determining the amount of tar and carbon oxides in the mainstream smoke were the same as those in previous studies (9, 11). The weight loss of a cigarette and the delivery of carbon oxides during a puff were measured simultaneously with the shortened tobacco column as reported previously $(11,23)$. In this case, the delivery of carbon oxides can be regarded as the amount formed during a puff, because the loss through the cigarette paper by diffusion is negligible. Therefore, the rates of formation of $\mathrm{CO}$ and $\mathrm{CO}_{2}$ were obtained from dividing the weight of $\mathrm{CO}$ and $\mathrm{CO}_{2}$ in the mainstream smoke during a puff by $W_{p}$ measured on the shortened tobacco column, respectively.

\section{Measurement of Peak Temperature}

All temperature measurements were made with a $\mathrm{Pt} / \mathrm{Pt}(87 \%)-\mathrm{Rh}(13 \%)$ thermocouple of $0.05 \mathrm{~mm}$ in diameter. Two thermocouples were inserted perpendicular to the longitudinal axis of a cigarette at points $15 \mathrm{~mm}$ and $25 \mathrm{~mm}$ from the front end so that the thermocouple junctions were located at the center of a cross section of the cigarette (13). After ignition, the electromotive force was recorded. When the paper burn line of static burn reached the first thermocouple, the temperature increased to the range of $640^{\circ} \mathrm{C}-680^{\circ} \mathrm{C}$. At this point, one puff was taken by a syringe-type smoking machine which draws $35 \mathrm{ml}$ of air over a period of two seconds. The same procedure was carried out when the paper burn line reached the second thermocouple. From twelve preliminary tests the coefficient of variation of the peak temperature measured during a puff was found to be less than $5 \%$. Generally, the temperature of the gas phase is measured by a thermocouple, and that of the solid phase by an infrared probe. The two phases are in near equilibrium in the period between puffs. During a puff, the two phases have very different temperature distribution near the surface of the burning cone. However, they are similar in the central region, where the temperature of the gas phase is highest (14-16). Therefore, the peak temperature measured by the present method can be regarded as an index which is representative of the combustion temperature of the burning cone during a puff.

\section{Analysis of Chemical Constituents of Tobacco}

After being powdered in a mill, all the tobacco samples were analyzed by the following conventional method. Total carbon was determined by a CHN recorder (Yanaco, MT-2 type), and water-soluble sugars by a colorimetric procedure involving a Technicon AutoAn- 
alyzer. The ethanol-benzene(1:2)-soluble portion was extracted from $5 \mathrm{~g}$ of tobacco powder for $48 \mathrm{~h}$ in a Soxhlet extractor. Then the portion of the residue soluble in hot water was extracted, and the remaining insoluble portion was regarded as cell-wall substances. The lignin content was obtained from the weight of the insoluble residue after hydrolysis of the cell-wall substances with $72 \% \mathrm{H}_{2} \mathrm{SO}_{4}$. The cell-wall substances were put through the extractor separately using $0.05 \mathrm{M}$ EDTA- $\mathrm{Na}_{2}$ (pH 4.5). The amount of pectin in the extract was calculated from the galacturonic acid content, which was determined colorimetrically. The insoluble fraction was treated with glacial acetic acid and sodium chlorite to remove lignin; holocellulose was obtained as the residue. Hexane extracts were determined gravimetrically after the desiccation of substances extracted with $n$-hexane for $40 \mathrm{~h}$ in a Soxhlet extractor. The nicotine content was determined by spectrophotometric analysis of the steam distillate. To determine the potassium content, $1 \mathrm{~g}$ of tobacco powder was stirred in $100 \mathrm{ml}$ of $2 \mathrm{~N}$ ammonium acetate solution $(\mathrm{pH} 6.9-7.1)$ containing $0.2 \mathrm{~N}$ magnesium acetate. The amount of potassium in an aliquot of filtered solution was determined by flame photometry using a Technicon AutoAnalyzer.

\section{Multiple Regression Analysis}

A stepwise multiple regression analysis was performed with a BMDP program on a Digital Equipment Corporation (DEC) VAX 11 computer using the RS/1 system (BBN Software Products Corp.).

\section{RESULTS AND DISCUSSION}

\section{Burning Characteristics and Smoke Components}

The amounts of $\mathrm{CO}, \mathrm{CO}_{2}$ and tar in the mainstream smoke and the burning characteristics measured with the shortened tobacco column are shown in Tables 2 and 3, respectively. As shown in Table 3, large variations were observed in the rate of formation of $\mathrm{CO}$ among the different kinds of tobacco, while the variations in the rate of formation of $\mathrm{CO}_{2}$ were found to be small. On the other hand, little variation in the weight loss of the cigarettes during a puff $\left(W_{p}\right)$ was observed. Figure 1 shows the relationships between the weight loss of a cigarette during $n$ puffs $\left(n W_{P}\right)$ and the amounts of $\mathrm{CO}, \mathrm{CO}_{2}$ and tar in the mainstream smoke. The slopes of the straight lines for $\mathrm{CO}, \mathrm{CO}_{2}$ and tar correspond to the mean values shown in the legend. The relationship among the variables given by the equation in the Introduction can also be applied to $\mathrm{CO}_{2}$ and tar. In this case, the term $\mathrm{D}$ must be replaced by the term $R$, which concerns the retention of tar by the butt. $R$ is considered to be almost constant for cigarettes with a given fractional volume. Therefore, the
Figure 1.

Smoke components vs. tobacco weight loss during puffs.

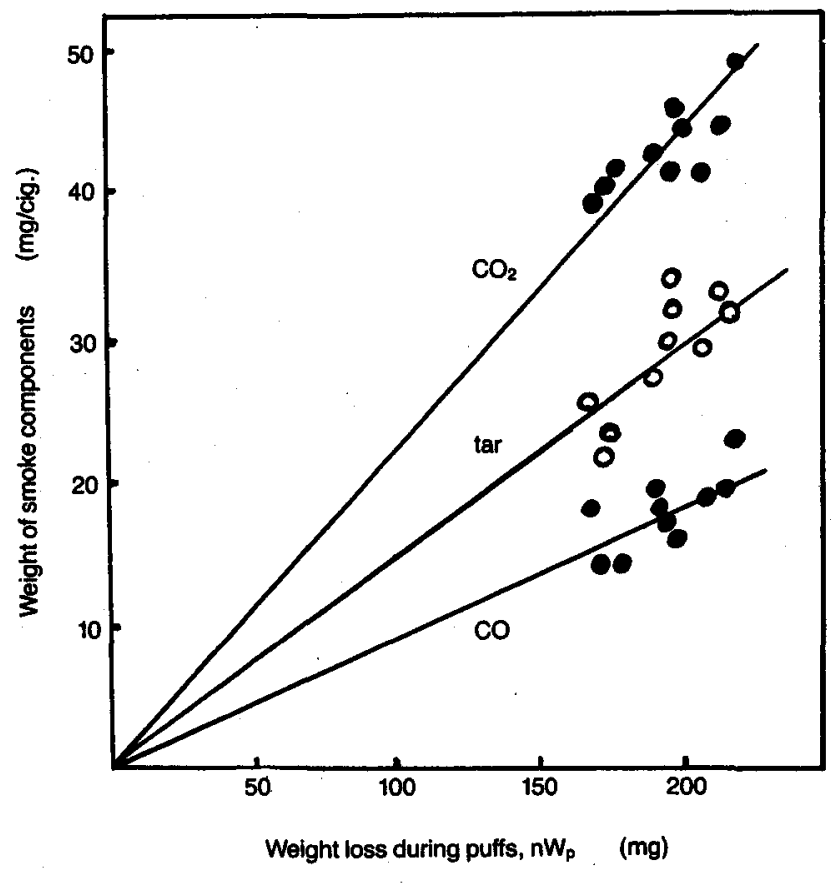

$$
\begin{array}{lccc} 
& \bar{x} & s & C . V . \\
\mathrm{CO} / \mathrm{nW} & 0.092 & 0.011 & 0.120 \\
\operatorname{tar} / \mathrm{nW}_{\mathrm{p}} & 0.150 & 0.015 & 0.100 \\
\mathrm{CO}_{2} / \mathrm{nW}_{\mathrm{p}} & 0.225 & 0.014 & 0.062
\end{array}
$$

slope of a line through the origin for each point in Figure 1 is an index of the rate of formation of each component. As can be seen, there are large variations in the slopes for $\mathrm{CO}, \mathrm{CO}_{2}$, and tar, although these compo-

\section{Figure 2.}

Formation rates of carbon oxides vs. their amounts in mainstream smoke.

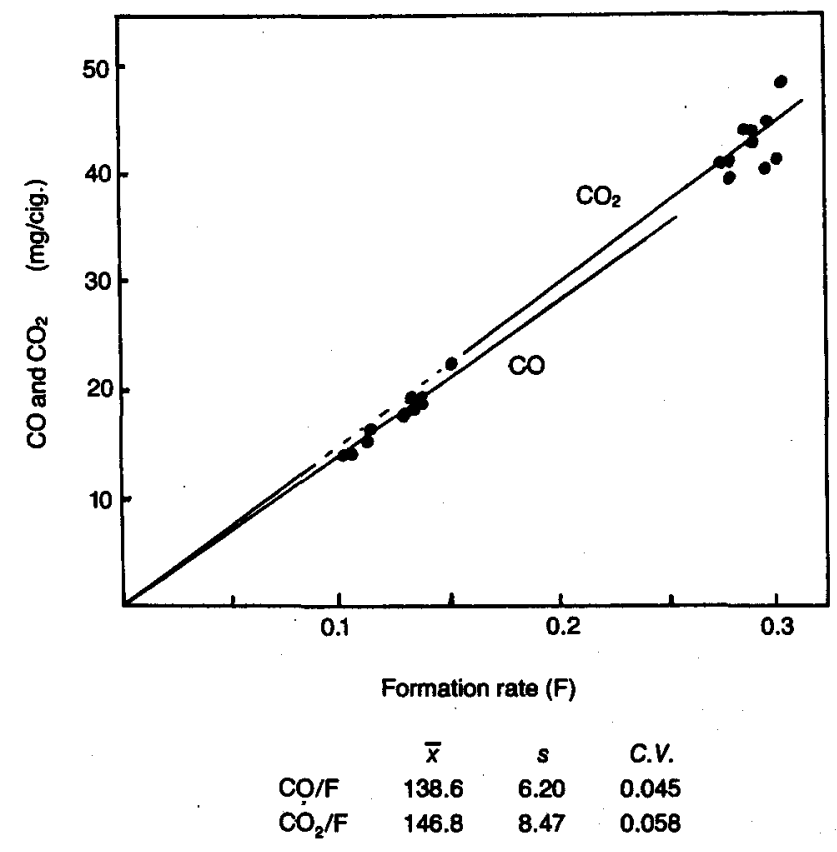


Table 2.

Carbon monoxide, carbon dioxide and tar in malnstream smoke.

\begin{tabular}{|c|c|c|c|c|c|c|c|}
\hline & Tobacco & $\begin{array}{c}\text { Puff } \\
\text { count } \\
(n)\end{array}$ & $\mathrm{CO}$ & $\begin{array}{c}\mathrm{CO}_{2} \\
\text { (mg/cigarette) }\end{array}$ & Tar & $\mathrm{CO} / \mathrm{CO}_{2}$ & $\mathrm{CO} / \mathrm{tar}$ \\
\hline \multirow{2}{*}{ A } & Cutter & 7.7 & 19.4 & 42.9 & 27.2 & 0.452 & 0.713 \\
\hline & Leaf & 9.1 & 22.9 & 48.7 & 31.9 & 0.470 & 0.718 \\
\hline \multirow{2}{*}{ B } & Cutter & 7.0 & 17.8 & 39.6 & 25.7 & 0.449 & 0.693 \\
\hline & Leaf & 7.6 & 18.3 & 41.0 & 29.9 & 0.446 & 0.612 \\
\hline \multirow[t]{2}{*}{$\mathrm{C}$} & Cutter & 8.0 & 18.8 & 40.8 & 29.3 & 0.461 & 0.642 \\
\hline & Leaf & 8.8 & 19.4 & 44.4 & 33.2 & 0.437 & 0.584 \\
\hline \multirow[t]{2}{*}{$\mathrm{D}$} & Cutter & 7.2 & 13.9 & 41.4 & 22.9 & 0.336 & 0.607 \\
\hline & Leaf & 8.0 & 16.7 & 45.7 & 34.3 & 0.365 & 0.487 \\
\hline \multirow[t]{2}{*}{$E$} & Cutter & 6.9 & 13.9 & 40.2 & 21.4 & 0.346 & 0.650 \\
\hline & Leaf & 7.8 & 15.7 & 44.0 & 32.0 & 0.357 & 0.491 \\
\hline
\end{tabular}

Table 3.

Burning characteristics.

\begin{tabular}{|c|c|c|c|c|c|}
\hline \multirow{2}{*}{\multicolumn{2}{|c|}{ Tobacco }} & \multirow{2}{*}{$\begin{array}{l}W_{p} \\
(m g)\end{array}$} & \multirow{2}{*}{$\begin{array}{l}n W_{p} \\
(m g)\end{array}$} & \multicolumn{2}{|c|}{ Formation rate $(F)$} \\
\hline & & & & $\mathrm{CO}$ & $\mathrm{CO}_{2}$ \\
\hline \multirow{2}{*}{ A } & Cutter & 24.40 & 189.7 & 0.136 & 0.291 \\
\hline & Leaf & 23.80 & 216.6 & 0.152 & 0.304 \\
\hline \multirow{2}{*}{ B } & Cutter & 23.50 & 164.5 & 0.132 & 0.286 \\
\hline & Leaf & 25.23 & 191.7 & 0.136 & 0.285 \\
\hline \multirow{2}{*}{ C } & Cutter & 25.67 & 205.4 & 0.139 & 0.281 \\
\hline & Leaf & 24.28 & 213.7 & 0.137 & 0.289 \\
\hline \multirow{2}{*}{ D } & Cutter & 24.27 & 174.7 & 0.102 & 0.303 \\
\hline & Leaf & 24.11 & 192.9 & 0.116 & 0.296 \\
\hline \multirow{2}{*}{$E$} & Cutter & 24.86 & 171.5 & 0.108 & 0.298 \\
\hline & Leaf & 25.16 & 196.2 & 0.114 & 0.288 \\
\hline \multicolumn{2}{|l|}{ Mean } & 24.53 & 191.7 & 0.127 & 0.292 \\
\hline \multicolumn{2}{|c|}{$\begin{array}{l}\text { Coefficient of } \\
\text { variation (\%) }\end{array}$} & 2.8 & 9.1 & 12.7 & 2.7 \\
\hline
\end{tabular}

Table 4.

Peak temperature during a puff.

\begin{tabular}{cl|c|c}
\hline & Tobacco & Mean $\left({ }^{\circ} \mathrm{C}\right)$ & \multicolumn{2}{c}{$\begin{array}{c}\text { Coefficient of } \\
\text { variation (\%) }\end{array}$} \\
\hline \multirow{2}{*}{ A Cutter } & 872 & 2.7 \\
& Leaf & 922 & 3.0 \\
B Cutter & 877 & 4.1 \\
& Leaf & 896 & 4.2 \\
C Cutter & 928 & 5.0 \\
& Leaf & 902 & 5.0 \\
D Cutter & 802 & 1.9 \\
& Leaf & 860 & 0.9 \\
E Cutter & 824 & 1.1 \\
\end{tabular}

$W_{p}$ : Weight loss during a puff measured on a shortened tobacco column.

$n$ : Puff count (values shown in Table 2). 
nents increased on the whole with increasing $n W_{p}$. The coefficient of variation was the highest for $\mathrm{CO}$, that for tar was next (legend of Figure 1). The precise effect is shown in Figure 2. All the points for CO fell nearly on a straight line passing through the origin. Some difference was observed between the mean values of the slopes for $\mathrm{CO}$ and $\mathrm{CO}_{2}$, which is reasonable because the term $\mathrm{D}$ is smaller for $\mathrm{CO}$ than for $\mathrm{CO}_{2}(8,9,17)$. The coefficient of variation for $\mathrm{CO} / \mathrm{F}$ (Figure 2) was smaller than that for $\mathrm{CO} / \mathrm{nW}$ (Figure 1). Hence, it can be concluded that the amount of $\mathrm{CO}$ in mainstream smoke is more dependent on the rate of formation of $\mathrm{CO}$ than the weight loss of a cigarette during puffs. On the other hand, from the fact that the coefficient of variation for $\mathrm{CO}_{2} / \mathrm{F}$ was almost equal to that for $\mathrm{CO}_{2} /$ $\mathrm{nW}_{\mathrm{p}}$, it can be concluded that the rate of formation of $\mathrm{CO}_{2}$ made about the same contribution to the amount of $\mathrm{CO}_{2}$ in mainstream smoke as did $\mathrm{nW}_{\mathrm{p}}$.

\section{Peak Temperature and Formation Rates of $\mathrm{CO}$ and $\mathrm{CO}_{2}$}

Table 4 shows the peak temperatures of the central region of a burning cone during a puff. The variation in temperature among the different kinds of tobacco was in the range $802^{\circ} \mathrm{C}$ to $928^{\circ} \mathrm{C}$. It was larger than the data measured for cigarettes made from different cultivars of tobacco $(18,19)$. This difference seems to be due to a large variation in the chemical constituents of the tobaccos used in this study, as will be discussed later. The relationship between the peak temperature and the rates of formation of $\mathrm{CO}$ and $\mathrm{CO}_{2}$ is shown in Figure 3. The rate of formation of $\mathrm{CO}$ increased with increasing temperature while that of $\mathrm{CO}_{2}$ remained almost constant. It was known that $\mathrm{CO}$ is formed by the pyrolysis of tobacco, the combustion of char and the carbonaceous reduction of $\mathrm{CO}_{2}$, and that the rate of $\mathrm{CO}_{2}$ formed by combustion and the rate of $\mathrm{CO}_{2}$ reduced to $\mathrm{CO}$ both increase with increasing temperature $(16,20,21)$. Therefore, one of the reasons for the increase in the rate of formation of $\mathrm{CO}$ shown in Figure 3 is considered to be an enhancement of the carbonaceous reduction of $\mathrm{CO}_{2}$ to $\mathrm{CO}$, which is promoted by higher combustion temperatures. The almost zero slope for the rate of formation of $\mathrm{CO}_{2}$ seems to be due to the fact that the increase in $\mathrm{CO}_{2}$ formation during combustion is compensated for by the decrease in $\mathrm{CO}_{2}$ as a result of carbonaceous reduction.

\section{Effect of Chemical Constituents}

The levels of several chemical constituents of the tobaccos are shown in Table 5. These tobaccos separate naturally into two groups because of considerable differences in their composition, i.e. into the group A, B, $C$, and the group D, E. The former contained somewhat smaller amounts of potassium, hexane extracts and cell-wall substances, and larger amounts of watersoluble sugars and ethanol-benzene extracts than did
Flgure 3.

Formation rates of carbon oxides vs. peak temperature.

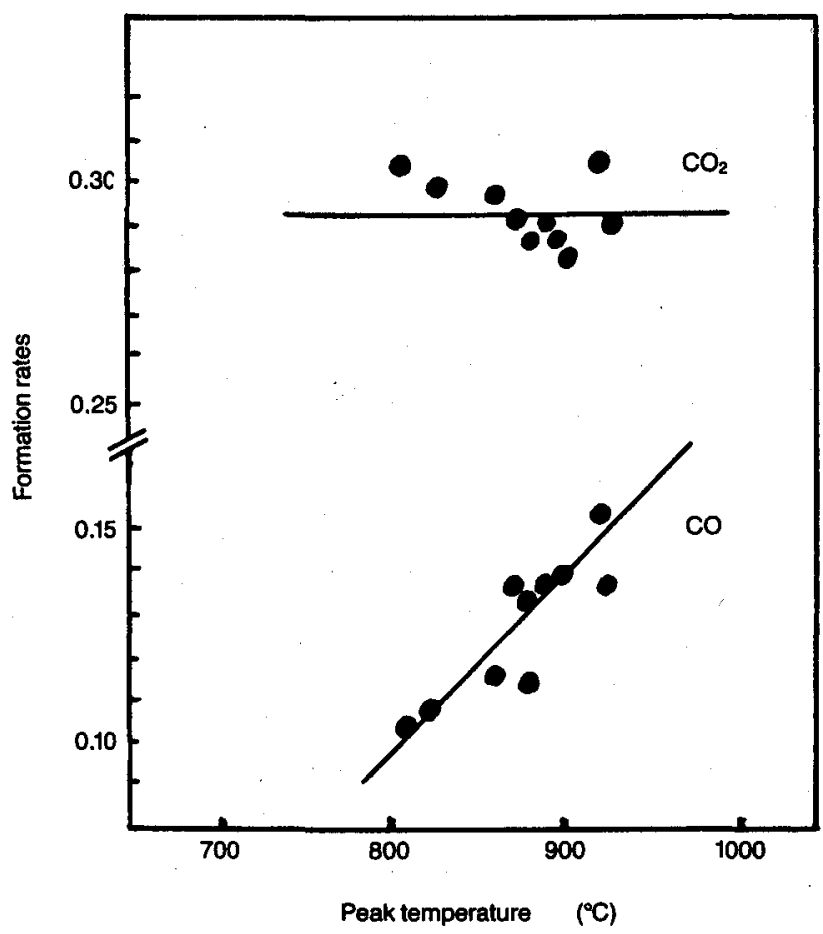

the latter. There was little difference in the total carbon content between the two groups, although a slightly higher content was observed in the leaf of $D$ and $E$. As is well known, the potassium content is lower in leaf

Figure 4.

CO/tar values in mainstream smoke vs. hexane extract contents of tobacco.

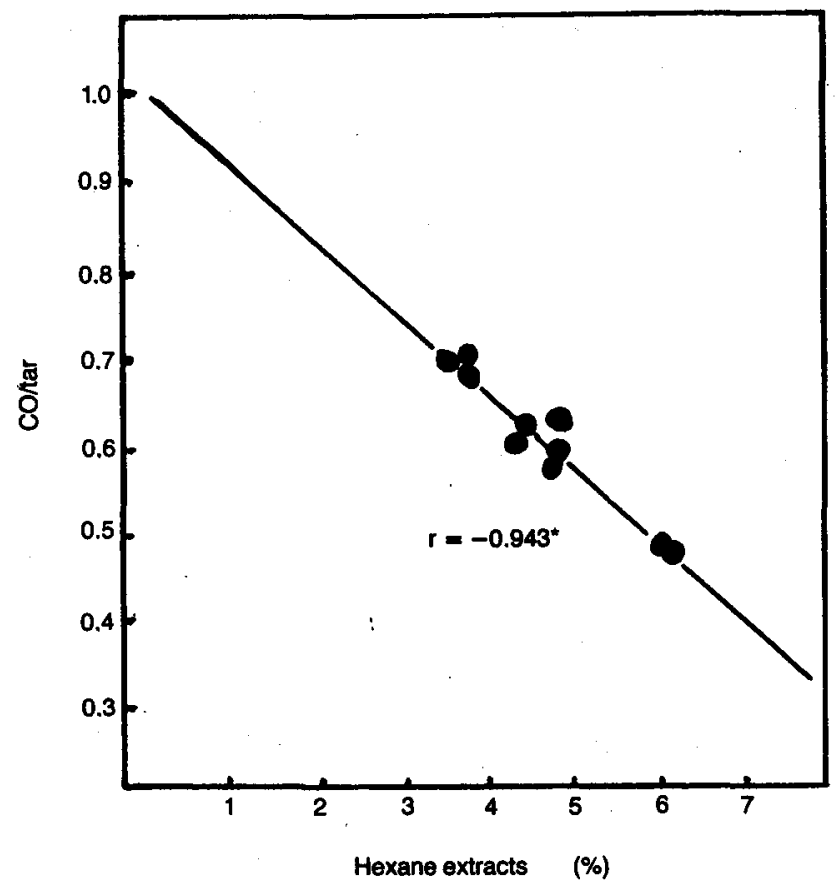

"Significant at the $1 \%$ level. 

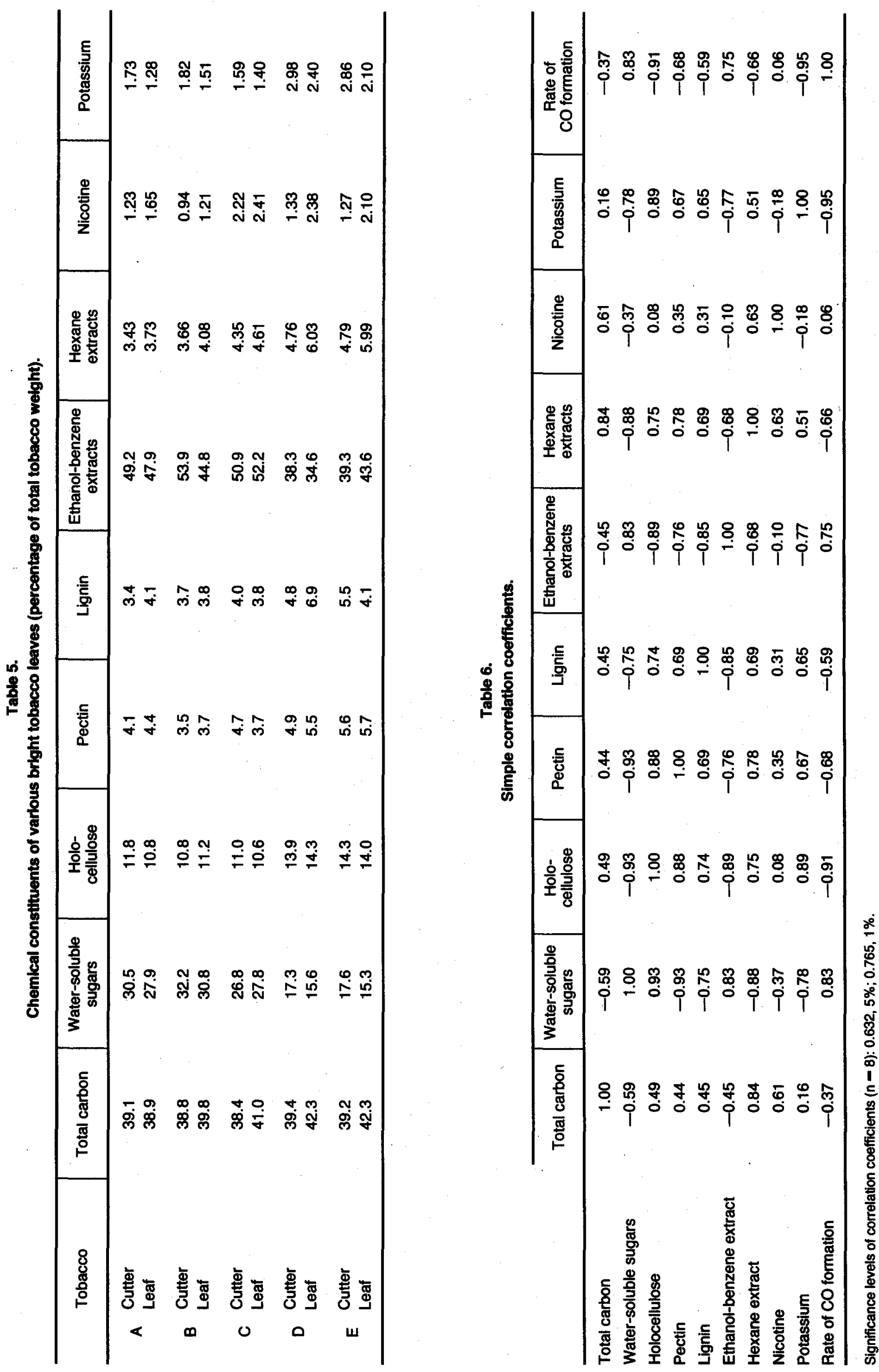
Figure 5.

Peak temperature vs. potasslum content of tobacco.

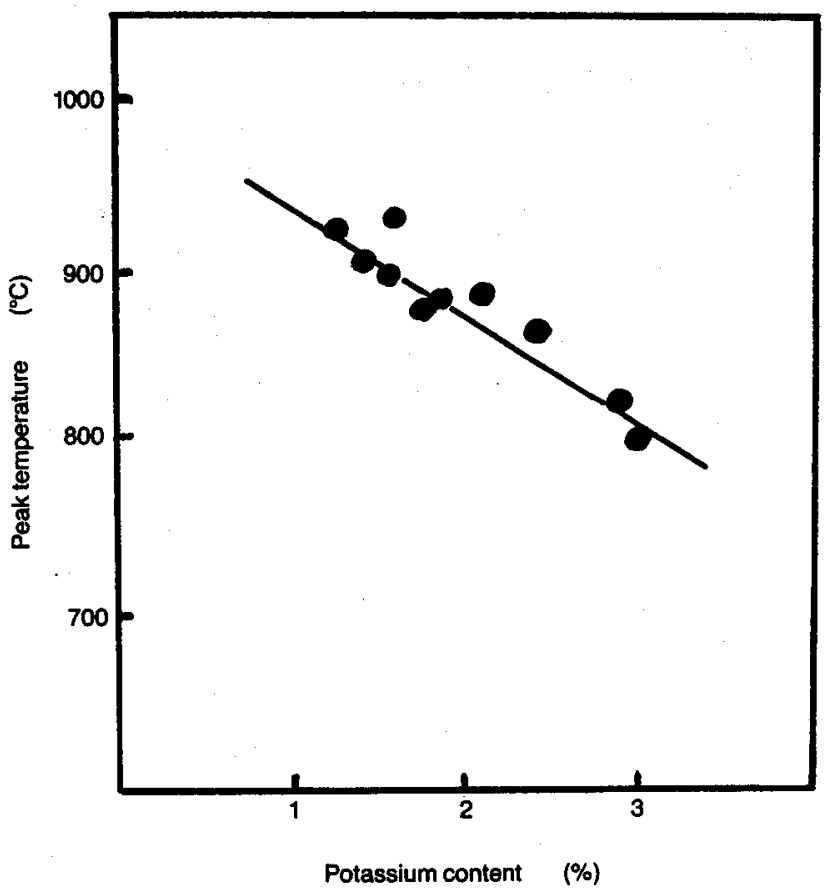

than in cutter tobacco, and there is an opposite tendency with regard to hexane extracts. Figure 4 shows a high negative correlation between hexane extracts and the CO/tar ratio in mainstream smoke. Since hexane extracts contain terpenoid and carotenoid compounds, which are considered desirable for the aroma of the smoke, it is suggested that the $\mathrm{CO} / \mathrm{tar}$ ratio might be an index of the strength of the aroma inherent in tobacco cultivars.

Table 6 shows the coefficients of simple correlations: Of the coefficients for chemical constituents vs. the rate of formation of $\mathrm{CO}$, the highest was potassium. In addition, it was found that the rate of formation of $\mathrm{CO}$ was negatively correlated with the cell-wall substances, and positively correlated with the water-soluble sugars. Based on these simple correlation data, several chemical constituents were selected and computations were performed on the rate of formation of $\mathrm{CO}[\mathrm{F}]$. The following are the equations and multiple regression coefficients for these computations:

step 1:

$$
F^{\prime}=0.1775-0.0256 \times(\text { potassium })\left[r^{2}=0.912\right],
$$

step 2:

$$
\begin{aligned}
F^{\prime}= & 0.2758-0.0246 \times(\text { potassium }) \\
& -0.0025 \times(\text { total carbon }) \cdot\left[\mathrm{r}^{2}=0.961\right],
\end{aligned}
$$

step 3:

$$
\begin{aligned}
F^{\prime}= & 0.3053-0.0284 \times(\text { potassium }) \\
& -0.0035 \times(\text { total carbon })+0.0036 \\
& \times(\text { lignin }) \quad\left[\mathrm{r}^{2}=0.987\right] .
\end{aligned}
$$

From the equations, it is concluded that the rate of for-
Figure 6.

Amount of $\mathrm{CO}$ in mainstream smoke vs. potasslum content of tobacco.

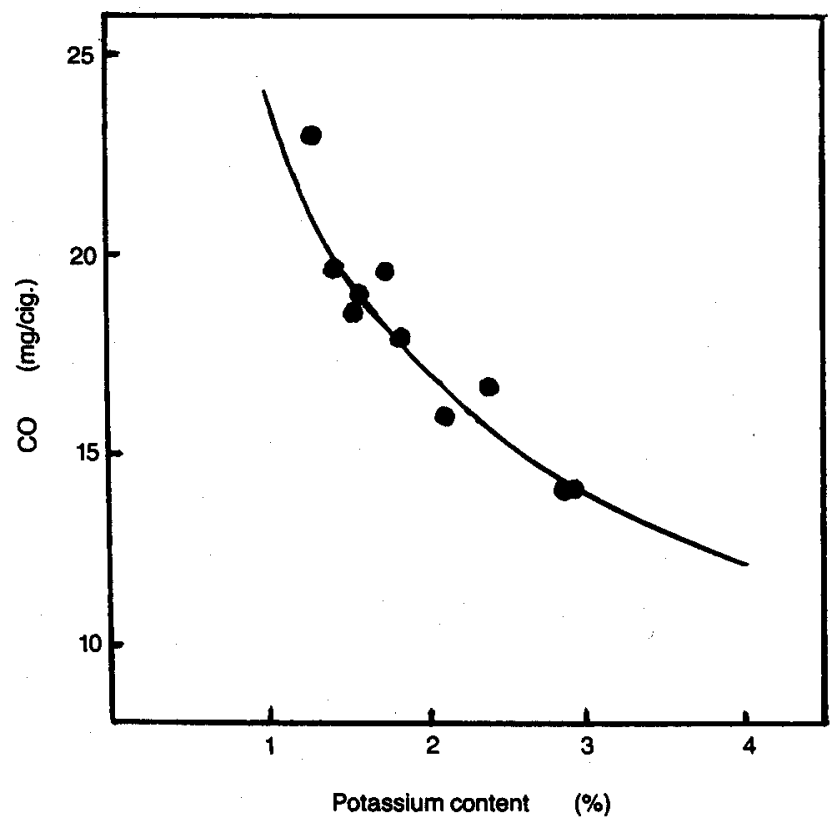

mation of $\mathrm{CO}$ depends mainly on the potassium content and can be estimated from the amounts of potassium, total carbon and lignin. A multiple regression analysis of the peak temperature $[\mathrm{T}]$ yielded the following equation:

$$
\begin{aligned}
\mathrm{T}^{\prime}= & 945.5-80.0 \times(\text { potassium }) \\
& +19.4 \times(\text { pectin })
\end{aligned}
$$$$
\left[\mathrm{r}^{2}=0.951\right]
$$

Table 5 shows a significance of $0.5 \%$ in the simple correlation between potassium and pectin. Therefore, the peak temperature seems to be mainly dependent on potassium. Peak temperature vs. potassium content is shown in Figure 5. As the potassium content increased from $1.3 \%$ to $3.0 \%$, the peak temperature decreased almost linearly from $928^{\circ} \mathrm{C}$ to $802^{\circ} \mathrm{C}$. As shown in Figure 3 , the rate of formation of $\mathrm{CO}$ increased with increasing peak temperature. These results lead to the conclusion that enhancement of the rate of formation of $\mathrm{CO}$ is due to a rise in burning temperature resulting from a decrease in the potassium content of the tobacco.

Figure 6 shows the relationship between the amount of $\mathrm{CO}$ in mainstream smoke and the potassium content. The amount of $\mathrm{CO}$ in mainstream smoke decreased sharply in the low range of potassium content $(1 \%-$ $2 \%$ ), and decreased gradually in the range of from $2 \%$ to $3 \%$. The curve in Figure 6 was obtained from a regression equation of the logarithmic values for both the variables. To clarify the effect of potassium on the combustion mechanism, further experiments are being performed in our laboratory. 


\section{REFERENCES}

1. Kiefer, J. E.: Ventilated filters and their effect on smoke composition; Recent Adv. Tob. Sci. 4 (1978) 69-83.

2. Owens, W. F., Jr.: Effect of cigarette paper on smoke yield and composition; Recent Adv. Tob. Sci. 4 (1978) 3m-24.

3. Mikami, Y., N. Naitō and Y. Kaburaki: Effects of some factors on carbon monoxide concentration in mainstream smoke of a cigarette; Jpn. Monop. Corp. Cent. Res. Inst. Sci. Pap. 113 (1971) 99-105.

4. Rathkamp, G., T. C. Tso and D. Hoffmann: Chemical studies on tobacco smoke, XX. Smoke analysis of cigarettes made from bright tobaccos differing in variety and stalk positions; Beitr. Tabakforsch. 7 (1973) 179-189.

5. Tso, T. C., G. Rathkamp and D. Hoffmann: Chemical studies on tobacco smoke, XXI. Correlation and multiple regression among selected cigarette-smoke constituents and leaf characteristics of bright tobacco; Beitr. Tabakforsch. 7 (1973) 190194.

6. Tso, T. C., and J. F. Chaplin: Simple correlation and multiple regression among leaf characteristics, smoke components and biological responses of bright tobacco; U.S. Dep. Agric. Tech. Bull. No. 1551, 1977.

7. Baker, R. R, and R. A. Crellin: The diffusion of carbon monoxide out of cigarettes; Beitr. Tabakforsch. 9 (1977) 131-140.

8. Muramatsu, M., T. Mikami, N. Naitō and H. Tomita: A model study on the diffusion and the dilution of low molecular weight gaseous components through cigarette paper during smoking; Beitr. Tabakforsch. 9 (1977) 141-146.

9. Yamamoto, T., Y. Suga, C. Tokura, T. Toda and T. Okada: Effect of cigarette circumference on formation rates of various components in mainstream smoke; Beitr. Tabakforsch. Int. 13.(1985) 81-87.

10. Katayama, Y., Y. Shimizu and J. Shimizu: A mercury displacement method for measurement of the apparent density of cut tobacco; Sen-i Gakkaishi 39, No. 4 (1983) 42-47.

11. Yamamoto, T., U. Anzai and T. Okada: Effect of cigarette circumference on weight loss during puffs and total delivery of tar and nicotine; Beitr. Tabakforsch. Int. 12 (1984) 259-269.

12. Yamamoto, T.: The effect of packing density, circumference and the kinds of shreds on the weight loss during a puff and carbon oxides delivery in the mainstream smoke; Jpn. Monop. Corp. Cent. Res. Inst. Sci. Paper 123 (1981) 1-8.
13. Muramatsu, M., Y. Obi, T. Fukuzumi and T. Keii: Influence of continuous puff velocity on combustion rate, temperature and temperature distribution of cigarette; J. Agric. Chem. Soc. Jpn. 46, No. 11 (1972) 569-575.

14. Baker, R. R.: Temperature variation within a cigarette combustion coal during the smoking cycle; High Temp. Sci. 7 (1975) 236-247.

15. Baker, R. R.: Environmental conditions inside a burning cigarette; Anal. Calorimetry 4 (1977) 193-202.

16. Baker, R. R.: Mechanism of smoke formation and delivery; Recent Adv. Tob. Sci. 6 (1980) 184-224.

17. Durocher, D. F., C. F. Mattina and W. A. Selke: Diffusion of gaseous components through the wrapper of a cigarette; Beitr. Tabakforsch. Int. 9 (1978) 201-207.

18. Lendvay, A. T., and T. S. Laszlo: Cigarette peàk coal temperature measurements; Beitr. Tabakforsch. 7 (1974) $276-281$.

19. Tancogne, J., B. Vidal et J. Chouteau: Etude du transfert dans la fumée des constituants du tabac extractibles par l'éther de pétrole; Ann. Tab. 17 (1981-82), section 2, 143-151.

20. Baker, R, R.: Formation of carbon oxides during tobacco combustion - Pyrolysis studies in the presence of isotopic gases to elucidate reaction sequences; J. Anal. Appl. Pyrolysis 4 (1983) 297334.

21. Baker, R. R.: The effect of ventilation on cigarette combustion mechanisms; Recent Adv. Tob. Sci. 10 (1984) 88-150.

\section{Acknowledgement}

The authors would like to express their gratitude to Dr. Y. Tatemichi for bis kind advice in this study, and to Mr. T. Sakaki for bis advice on bow to use a computer.

\section{Authors' address:}

Central Research Institute, Japan Tobacco Inc., 6-2 Umegaoka, Midori-ku, Yokohama, Kanagawa, 227, Japan. 